\title{
EMBLEMAS DOCTRINALES
}

\author{
DOCTRINAL EMBLEMS
}

Rafael Zafra

Universidad de Navarra

$A$ Victor Infantes.

Gracias por esa conversación que no tuvimos

\begin{abstract}
This study proposes to determine the emblematic character of a type of catechetical-doctrinal composition, influenced by Alciato's Emblems, that emerged at the height of the dispute between Catholics and Protestants and their attempt to refute and extend their contradictions and respective doctrines. Starting from the notion that the emblem is a "transfigured common place», I analyze the massive use of these commonplaces in theological and doctrinal treatises, and conclude that both the compositions that formed the catechisms and emblematized sums, as well as many of the paintings and other artistic compositions that derive from them, can be considered emblems in their purity, though not in a figurative sense, and constitute a category that can be called doctrinal emblems.
\end{abstract}

KEYWORDS: Emblem Theory; Doctrine; Catechesis; Reform; Commonplaces.

RESUMEN • Este trabajo trata de determinar el carácter emblemático de un tipo de composiciones catequetico-doctrinales surgidas, por influencia de los Emblemas de Alciato, en el momento cumbre de la disputa entre católicos y protestantes y su intento de refutar y extender sus contrarías y respectivas doctrinas. Partiendo de un concepto de emblema como "lugar común transfigurado" y tras analizar el empleo masivo de estos lugares en la tratados teológicos y doctrinales, se acaba concluyendo que tanto las composiciones que conformaron los catecismos y sumas emblematizadas como muchos de los cuadros y otras composiciones artísticas que de ellos se derivan, pueden ser considerados emblemas en puridad y no en sentido traslaticio, y constituyen una categoría a la que se puede denominar emblemas doctrinales.

PALABRAS CLAVES: Teoría del emblema; Doctrina; catequesis; Reforma; Lugares comunes. 
Hace ya unos años dedique un trabajo (Zafra, 2008) a la Suma de la doctrina cristiana de San Pedro Canisio, libro que edité algo más tarde (2014), y que puede considerarse la manifestación máxima de la catequesis jesuítica y contrarreformista. Presté especial atención a sus versiones ilustradas, «emblematizadas» y a su posible influencia en el arte de la contrarreforma.

En aquella ocasión deje pendiente de resolución -no tenía entonces las herramientas conceptuales para ello- la cuestión de si las composiciones que estructuran estos catecismos ilustrados -en especial la editada por Phi-

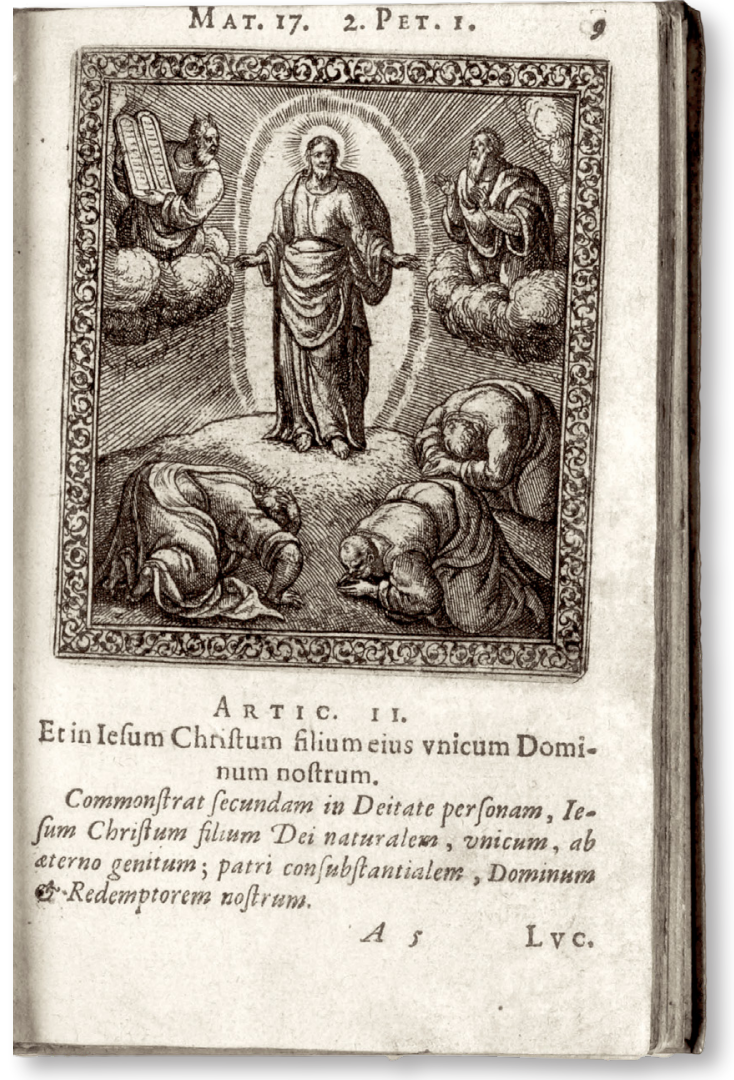

Fig. 1. Canisio, Instituciones cristianx..., 1589: 9. lip Galle y Christoforo Plantin (Institutiones Christianx pietatis, 1589), con grabados de Pieter van der Borcht- eran o no verdaderos emblemas; si se les podía aplicar con propiedad ese nombre o debían pasar a engrosar la nómina de obras que conforman la Marginalia emblemática, esas obras que sistemáticamente estudió el añorado Victor Infantes, al que agradezco desde aquí sus ánimos para seguir trabajando en ese sentido.

Desde entonces he dedicado varios estudios a la naturaleza del emblema (Zafra 2014 y 2017), intentando determinar lo verdaderamente constitutivo de estas composiciones, y en esta ocasión voy a tratar de aplicar esos resultados a estas obras emblemático-doctrinales.

Entremos en materia: si observamos una de las composiciones que conforman la edición de Gallé y Plantin, -por ejemplo la correspondiente al segundo artículo del credo: "Creo en Jesucristo su Único Hijo, Nuestro Señor» [fig.1]-, se puede observar que, desde un punto de vista formal, posee los tres elementos que definen un emblema según la opinión más generalizada:

1. El artículo del credo es el lema,

2. la imagen de la Transfiguración del Señor conforma la pictura y

3. la respuesta del catecismo hace las veces de subscriptio o comentario.

Además si comparamos otra de estas composiciones, por ejemplo, la correspondiente al cuarto precepto del decálogo, "Honra a tu Padre y a tu madre y tendrás una vida larga sobre la tierra», [fig. 2] con uno de los emblemas de Alciato, el D195: "La piedad de los hijos para con los padres» [fig. 3], se puede observar que ambas funcionan de un modo bastante parecido como glosas visuales del lugar común de la piedad filial. ${ }^{1}$

1. Empleo la edición de Plantin, Leiden 1591 que fue hecha en las mismas prensas que las Institutiones de Canisio solo dos años más tarde, con los mismos tipos y con una disposición casi idéntica. Los grabados de las ediciones 


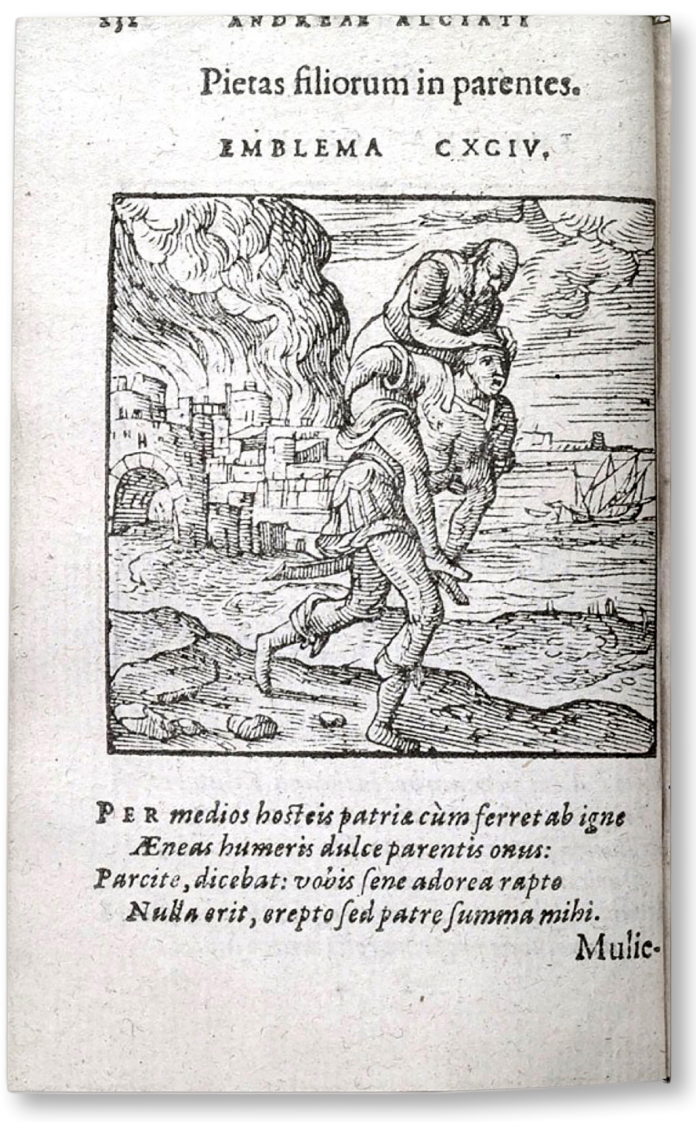

Fig. 2. Alciato, 1591: 57.

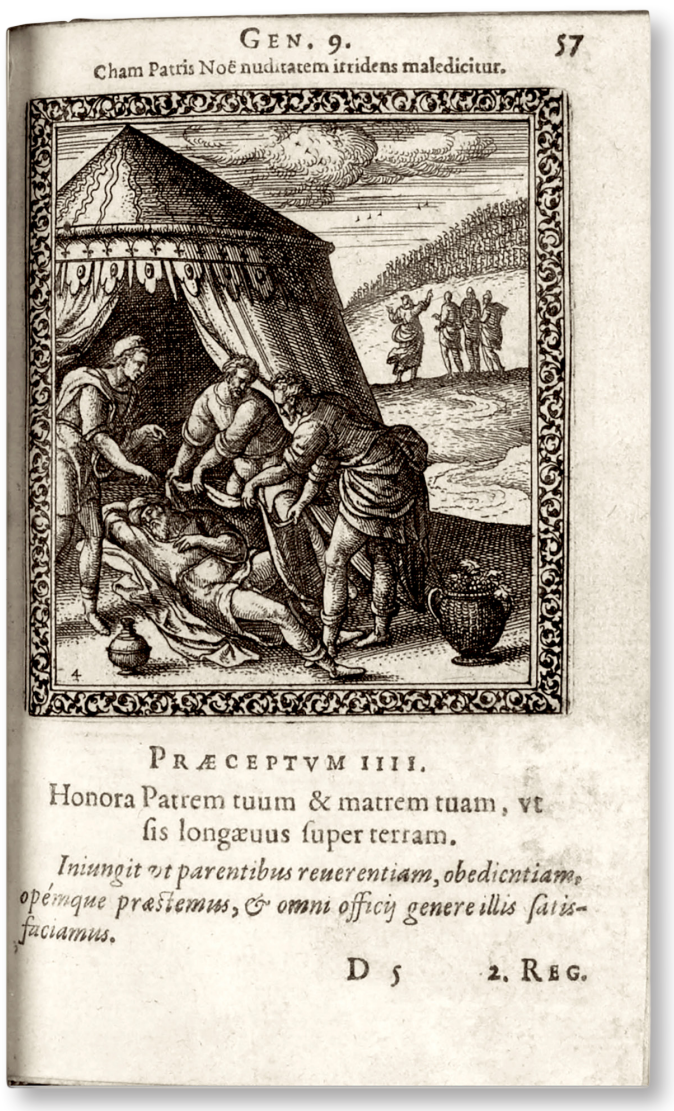

Fig. 3. Canisio, 1589: 57.

Desde un punto de vista formal, sería posible concluir que estamos pues ante emblemas y se podría catalogar este catecismo como un libro de emblemas, resaltando además su importancia por ser el primero del género con carácter puramente emblemático.

Sin embargo, esta consideración del emblema desde un punto de vista exclusivamente formal deja fuera muchas manifestaciones que con una perspectiva más profunda y, a mi modo de ver, más exacta, serían claramente emblemáticas. Es lo que sucede, por ejemplo, con aquellos cuadros derivados de emblemas y que, aunque no tienen subscriptio, ni lema, poseen el mismo sentido y parecida forma que los emblemas de los que proceden.

El cuadro de F. Barocci, La huida de Eneas de Troya (1589, Roma, Galeria Borghese) [fig. 4], no es meramente una imagen hermosa de la huida de Eneas de Troya en llamas, sino un constante recordatorio para todos los que lo contemplan de que deben cuidar sus ancianos padres y ser piadosos con ellos. ${ }^{2}$ Tanto es así que la mera mención de Eneas y Anquises se convirtió en un conocidísimo lugar común, en un «emblema», de la piedad filial. (Véase también Zafra, 2010).

plantinianas fueron diseñados también por van der Borcht y grabados por Arnaud Nicolai (Tung, 2010) imitando los de Virgilio Solis, el mismo grabador que, como veremos más tarde, hizo las imágenes que acompañaron los epigramas de Melanchton en la edición de Camerarius. Sobre las ediciones de Alciato véase el estudio de la de 2003.

2. Este posible carácter moral de fondo justificaría la existencia de esta obra, la única de carácter profano conocida de su autor Francesco Barocci.

IMAGO, NÚM. II, 2019, 85-95 


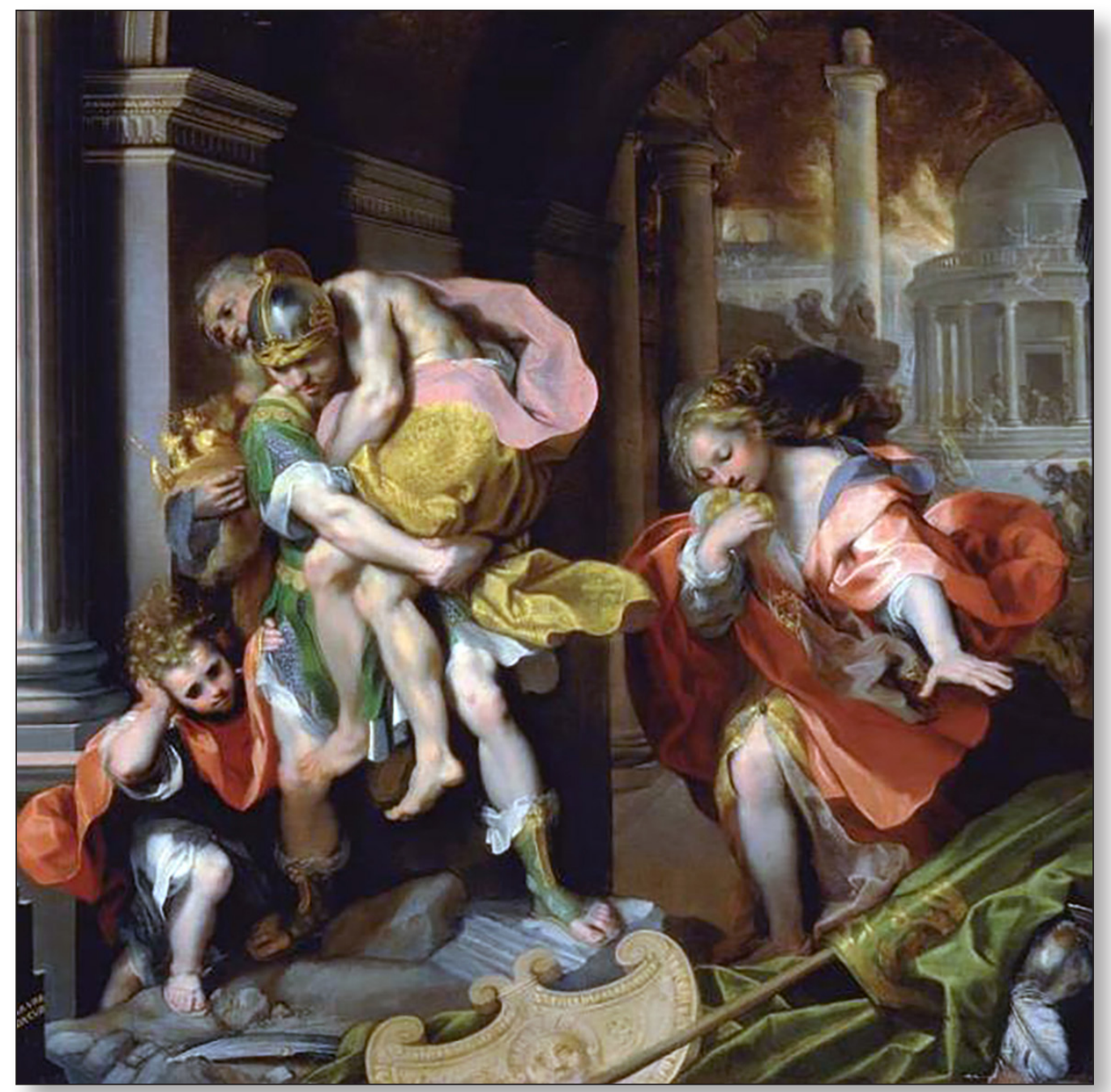

Fig. 4. Barocci, F., detalle de La huida de Eneas de Troya, Roma, Galeria Borghese, 1589 (detalle).

Como ya expliqué en trabajos previos (Zafra, 2017), considero un emblema un lugar común transfigurado, desautomatizado, mediante la combinación de una sentencia y/o un epigrama, y/o una imagen, que se complementan, especifican o amplifican mutuamente.

Entiendo por lugar común $n^{3}$ cualquier enseñanza de la experiencia humana susceptible de repetición y por ello merecedora de transmisión, que se encapsula en forma de sentencia, concepto, aforismo, epigrama, emblema, autoridad, fábula o exemplum, y que por su antigüedad, su extensión o el prestigio de su autor se tiene comúnmente como cierta, se cree responde a la realidad de las cosas.

3. Respondo así a la pregunta que Antonio Bernat me planteo al exponer la primera versión de este trabajo en el congreso sobre Emblemática y Religión celebrado en Oporto en 2008 y en cuyas actas (Arellano, 2010) no quise publicar este trabajo al no tener resuelta esta cuestión clave. 
Este sentido de «lugar común» el del inglés commonplace, está tomado del latín para significar, en un proceso de metonimia, todas aquellas cosas -especialmente las sentenciassusceptibles de ser recogidas en recopilaciones organizadas por loci comunes, commonplaces, «lugares comunes», aquellas categorías por las que se suelen agrupa. Por este motivo a veces se verá usar este termino para referirse tanto al continente, «diez mandamientos» o "prudencia», como al contenido, "amaras a Dios sobre todas» o "vino prudencia augeri»

En el campo de la doctrina cristiana al que pertenecen los libros que estoy tratando, y en el Teología de la que proceden, la fuente principal de lugares comunes es sin duda la Sagrada Escritura, especialmente el Nuevo Testamento. Sin embargo, con el paso del tiempo, la elaboración académica dio lugar a diversos tratados entre los que destacan la Suma Teológica de Santo Tomás de Aquino y, sobre todo el Libro de las Sentencias de Pedro Lombardo, texto de estudio obligatorio en las universidades hasta fines del barroco.

La Reforma luterana que, por su propia naturaleza, supuso un enorme cambio doctrinal y teológico, expuso sus ideas a través, primero, de los catecismos del propio Lutero y, después, de un modo más desarrollado en los Loci communes rerum theologicarum (Basilea, 1521) de Felipe Melanchthon.

La Iglesia Católica, por su parte, vio surgir como réplica un buen numero de libros de entre los que destacan el De Locis Teologici de Melchor Cano, y sobre todo los catecismos emanados del Concilio de Trento, entre ellos la Suma de la doctrina cristiana de Canisio, del que la versión ilustrada que estamos tratando, Institutiones Christianæ pietatis, es un breve resumen.

La Suma de Canisio (2014) responde al mandato de la sesión general del Concilio de abril de 1546 para que se compusiera un manual que pudiese sustituir al de Pedro de Lombardo, y que, dejando de lado el método escolástico, expusiera mediante sentencias de la escritura y de los Padres los lugares de la doctrina cristiana (Canisio, 2014, 45*-48*).

Tomando como estructura los tradicionales lugares comunes de la doctrina cristiana (artículos del Credo, peticiones del Padrenuestro, mandamientos, sacramentos, etc...) Canisio fundamenta cada uno ellos en pasajes del Nuevo Testamento, y los glosa con lugares del Antiguo y de los Padres de la Iglesia, siguiendo el método habitual en los humanistas.

Este método es muy similar al que empleaba Alciato, tanto al explicar las sentencias del Digesto en sus tratados jurídicos, como al amplificar las sentencias o epigramas que dieron lugar a su Embletum liber, y que sirvió de modelo para las composiciones que estoy analizando (Zafra, 2009). Esta similitud, se manifiesta también en cómo los emblemas de Alciato, que en un principio estaban dispuestos en un orden cronológico, adoptaron pronto una organización en lugares comunes (Dios, religión, vicios, virtudes, el príncipe...), que, aunque fue realizada por Bartolomé Aneau (Alciato 2003, 19-20), fue aceptada por el autor, que la empleo en todas sus ediciones posteriores.

Los Emblemata tuvieron en pocos años un gran número de ediciones, realizadas por distintos impresores en competencia y fueron traducido a las principales lenguas: francés, alemán, inglés, italiano, español. Este éxito mostró a un mundo en el que se estaba generalizando la retórica, y por tanto el empleo de libros de lugares comunes para la argumentación de todo tipo, cómo se podía emplear una imagen para glosar estos lugares y conseguir así su fijación en la memoria de un modo casi instantáneo, y por ello, en seguida se traspasó a otros campos que empleaban el mismo tipo de recursos.

De especial aplicación resultó en el campo de la educación, la catequesis, y la apología de la religión en un momento tan complejo como fue éste de la Reforma del cristianismo y de la Iglesia en el S. XVI. En este debate en el que, como he señalado, los teólogos protestantes y católicos echaban mano de todo el arsenal retórico, de todas las fuentes de la 
argumentación, de todos los lugares comunes, enseguida fue apreciado el gran potencial de unas imágenes que encerraban un contenido profundo y cargado de autoridad.

No es casual que en plena explosión del género emblemático, ya en la segunda mitad del siglo XVI, la iglesia Católica en el Concilio de Trento ordenara en el conocido decreto sobre las sagradas imágenes de la sesión 25 del Concilio:

Enseñen diligentemente los obispos que por medio de las historias de los misterios de nuestra redención, expresadas en pinturas y en otras imágenes, se instruye y confirma al pueblo en los artículos de la fe, que deben ser recordados y meditados continuamente y que de todas las imágenes sagradas se saca gran fruto, no sólo porque recuerdan a los fieles los beneficios y dones que Jesucristo les ha concedido, sino también porque se ponen a la vista del pueblo los milagros que Dios ha obrado por medio de los santos y los ejemplos saludables de sus vidas, a fin de que den gracias a Dios por ellos, conformen su vida y costumbres a imitación de las de los santos, y se muevan a amar a Dios y a practicar la piedad.

Quienes quiera que estén detrás de este decreto -extremo que estoy en estos momentos estudiando- conocerían sin duda la obra de Alciato, y se dieron cuenta de las posibilidades propagandísticas -en el sentido originario de propaganda fide-que encerraban sus emblemas, como los protestantes ya habían empezado a hacer.

Estos, con el humanista Melanchthon a la cabeza, estaban ya empleando con gran profusión los loci comunes en la justificación de su doctrina, y también utilizaban las imágenes tanto en la educación de los niños -por ejemplo el catecismo pequeño de Lutero- como en el ataque a los católicos. Sin embargo en la medida en que en virtud del libre examen -sobre todo

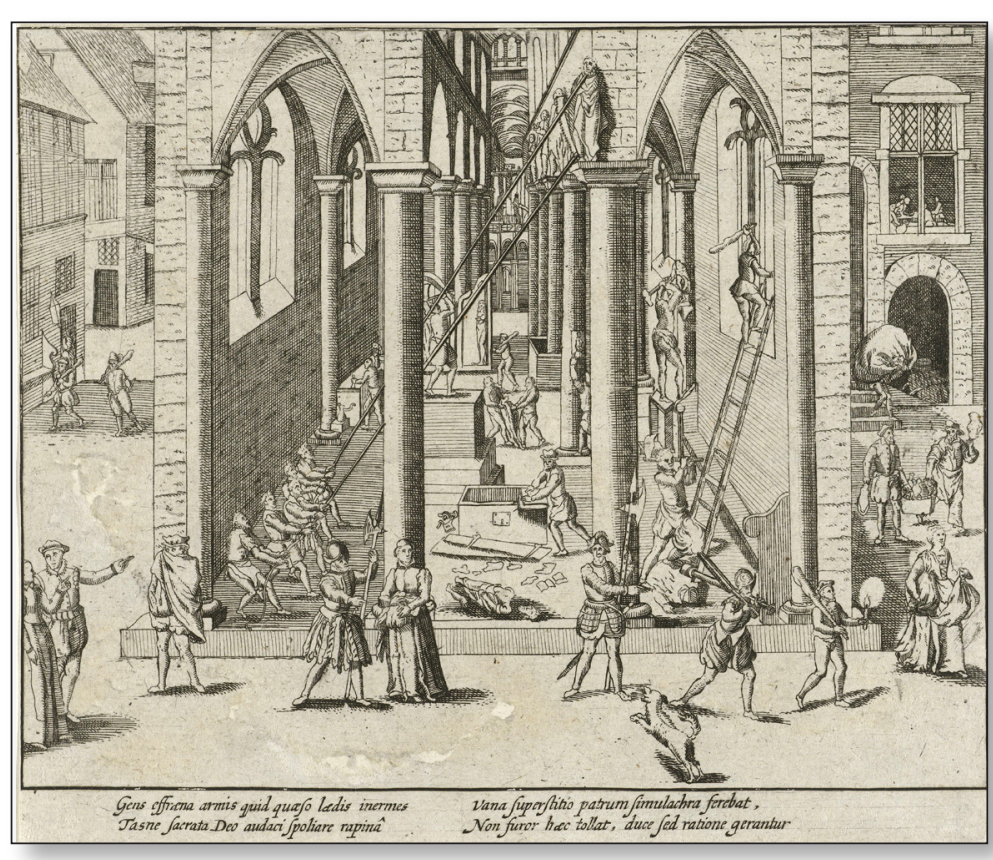

Fig. 5. Frans Hogenberg, La furia iconoclasta, 1566. en la rama Calvinistase fue rechazando cualquier manifestación del principio de autoridad, también -en algunos casos con enorme virulencia- ésta que tan directamente llegaba al corazón de los iletrados. Baste recordar como ejemplo extremo la furia iconoclasta desatada en los países bajos Calvinistas entorno a las mismas fechas que el decreto de Trento recomendaba el empleo de las imágenes sagradas [fig. 5]. ${ }^{4}$

Esta propuesta fue recogida -como es bien sabido- especialmente

4. Incluyo como figura 5 el conocido grabado La furia iconoclasta calvinista del protestante Frans Hogenberg (1566) porque curiosamente tiene también, como todo el libro al que pertenece, forma de emblema. 
por la Compañía de Jesús, ya muy aficionada a las imágenes y a los libros ilustrados como ayuda para la compositio loqui del método de oración ignaciano, y que podemos considerar otra forma de visualización de un lugar común espiritual. Posiblemente estas concomitancias entre la técnica emblemática y esta composición de lugar, junto a su profunda relación con la retórica, hizo que la Compañía cultivara con tanta profusión las distintas formas del género emblemático y las empleara en la formación de los alumnos de sus colegios.

El abandono de la imagen por parte de los protestantes frenó en su bando una catequesis que podría haberles dado grandes frutos y, posiblemente, ayudó no poco a la recuperación para el catolicismos de amplios sectores del Imperio, especialmente gracias a su empleo masivo por la Compañía de Jesús

Éste es el ambiente en el que heterodoxo el impresor y humanista Christoforo Plantin, ante los beneficios que estaban suponiendo la venta de libros ilustrados, sugirió a Pedro Canisio,, superior de los jesuitas en Alemania y autor de la mencionada Suma de la Doctrina Christiana-catecismo obligatorio en todo el Imperio y los Países Bajos y convertido de facto en el catecismo oficial de la Compañía-, la posibilidad de hacer una versión ilustrada, emblematizada de su catecismo, siguiendo los mandatos del decreto de Trento.

Plantin, que en aquellos momentos estaba plenamente dedicado al lucrativo negocio de la edición y venta de los emblemas de Alciato -el ejemplar que he presentado antes procede de sus prensas-, apreció la relativa facilidad con que se podría convertir en emblemas la doctrina católica que Canisio había estructurado mediante sentencias, organizadas por lugares doctinales, como había hecho Alciato al recopilar los lugares comunes que conforman su obra.

En colaboración con Philip Galle y con la ayuda del buril de Pieter Van der Borcht, transfiguraron las sentencias, los lugares comunes de la Doctrina cristiana, ilustrándolos con una imagen -a menudo de escena doble-, amplificando y concretando su sentido con un pasaje del antiguo testamento.

Unos años antes de estas Institutiones Christianx (1589) e imitando los catecismos ilustrados que la precedieron, Sigmund Feyerabent, uno de los principal competidores de Plantin en el campo luterano, especialmente con sus ediciones de los emblemas de Alciato, había publicado un libro similar que tomaba como base las obras de Melanchthon, en especial los Loci communes rerum theologicarum. Con la colaboración de Joachim Camerarius -uno de los principales humanistas protestantes y autor de conocidos libros de emblemas-, combinó diversos epigramas y lugares de Melanchthon con los grabados que el mismo había hecho junto con Virgilio Solis ${ }^{5}$ para sus ediciones de la Biblia, en un libro muy hermoso pero menos claro y eficaz que el de su competidor flamenco. Se trata de Epigrammata Philippi Melanthonis selectiora, publicado en Francfort en 1583 [figs. 6 y 7] que también debió servir a Plantin como modelo.

Como puede verse en estos ejemplos, la relación entre las imágenes y los lugares doctrinales a los que acompañan resulta menos clara que en la edición de Plantin, pese a que a menudo ambos emplean las misma escena para glosar idéntico pasaje. Pero no por ello deja de establecerse la misma solida relación entre la sentencia - «no tomarás el nombre de Dios en vano»- y la imagen que la amplifica y determina -la lapidación del blasfemo de Lev. 24-, para dar lugar a un emblema del segundo de los mandamientos.

5. Otra muestra del la similtud de ambas obras y su estrecha relación con la obra de Alciato es el hecho de que Virgil Solis hiciera los grabados de los emblemas editados por Sigmund Feyerabend, del mismo modo que Pieter Van der Borcht, ilustrador del Canisio, había hecho los de las ediciones de Plantino.

IMAGO, NÚM. I I, 2019, 85-95 


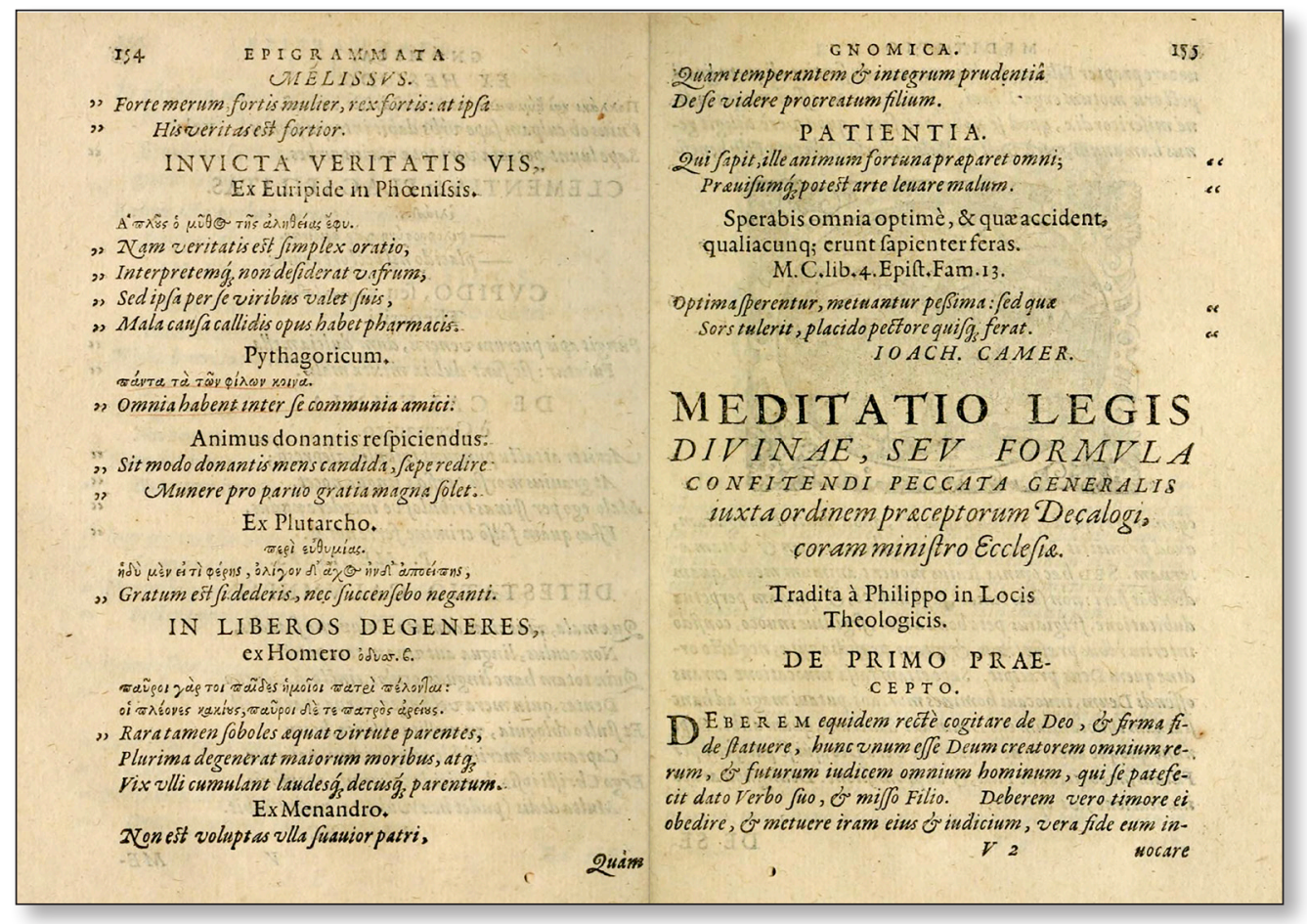

Fig. 6. Epigrammata Philippi Melanthonis selectiora..., 1589: 154-155.

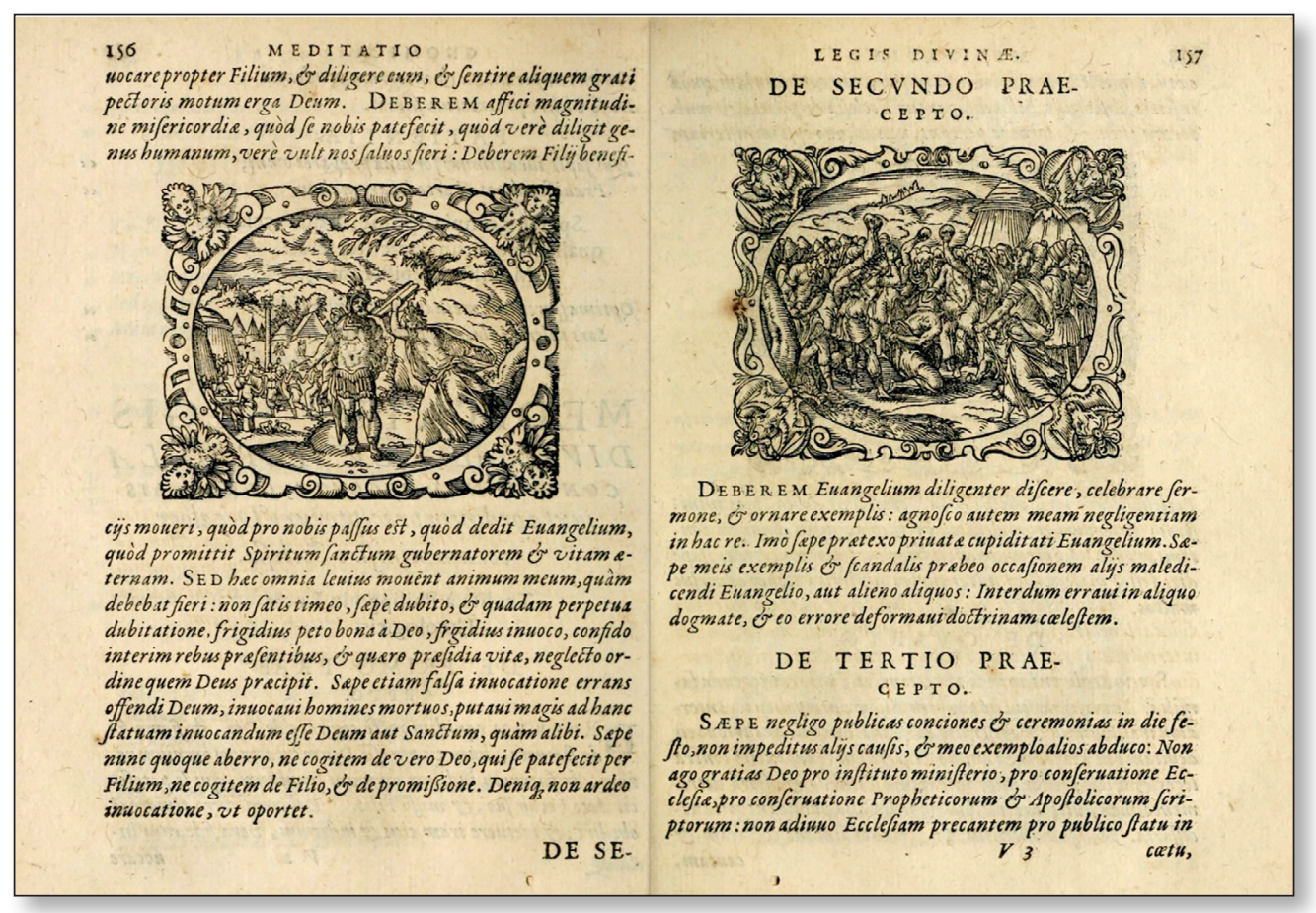

Fig. 7. Epigrammata Philippi Melanthonis selectiora..., 1589: 156-157. 
Los dos libros consiguen transfigurar los lugares doctrinales en los que se basan para dar lugar a un tipo de composiciones tan emblemáticas como las del mismo Alciato, y a las que podemos denominar «emblemas doctrinales», como se dominó, por ejemplo, Emblemas médicos a los que compuso Louis de Caseneuve a partir de lugares y sentencias de Hipócrates (López Poza, 1993).

En ambos casos queda claro también, como sucedía con los libros de Icones (Zafra, 2014), que en el proceso de creación de estos libros no debe minusvalorarse el papel de los grandes empresarios editores que veían en ellos, por estar tan de moda, una buena oportunidad de rentabilizar la inversión hecha en grabados en principio destinados a otras obras.

Algo similar sucede con obras como las versiones emblematizadas de las Metamorfosis de Ovidio, ilustradas por Virgil Solis, Passe o Salomon, y sintetizadas en forma epigramática por Salsmann o Ludovico Dolce. Quede esto para otro autor u otro trabajo.

En el ámbito de los cuadros religioso, como ya señale en otras ocasiones (Zafra, 2008 y Canisio, 2014), citando para ello el siguiente pasaje de Juan de Butrón, este tipo de obras tuvieron gran influencia:

\begin{abstract}
Para catequizar la Iglesia a los hijos que quieren criarse debajo de sus alas, halló una maravillosa invención el padre Juan Bautista Romano, y después dél, el padre Pedro Canisio, ambos de la Compañía de Jesús, que pusieron todos los rudimentos con que se deben dotrinar los idiotas, y enseñar los niños desde el per signum crucis hasta la última de las oraciones que la Iglesia tiene, por estampas, que alientan el afecto aprehendiendo lo que allí se les muestra, imitando lo que se les pone pintado (Butrón, 1626, fol. 90v ).
\end{abstract}

Teniendo esto en cuenta, es muy plausible que muchos cuadros que cuelgan de las Iglesias Católicas, pese a que no tengan pintura ni epigrama, se deban interpretar no como meras escenas figurativas sino como emblemas doctrinales que esperan a un predicador que explique la escena y extraiga la enseñanza que encierra de modo que quede sólidamente grabada en la memoria de los fieles. Valga como ejemplo el óleo de Murillo La paciencia del Santo Job [fig. 9] que bien podría ser al mismo tiempo un emblema de la segunda de las buenaventuras - «Benditos los pobres de espíritu: porque de ellos es Reino de los Cielos»-como sucede en las Instituciones cristianx pietatis de Canisio que pudieron servir a su autor de inspiración [fig. 8].

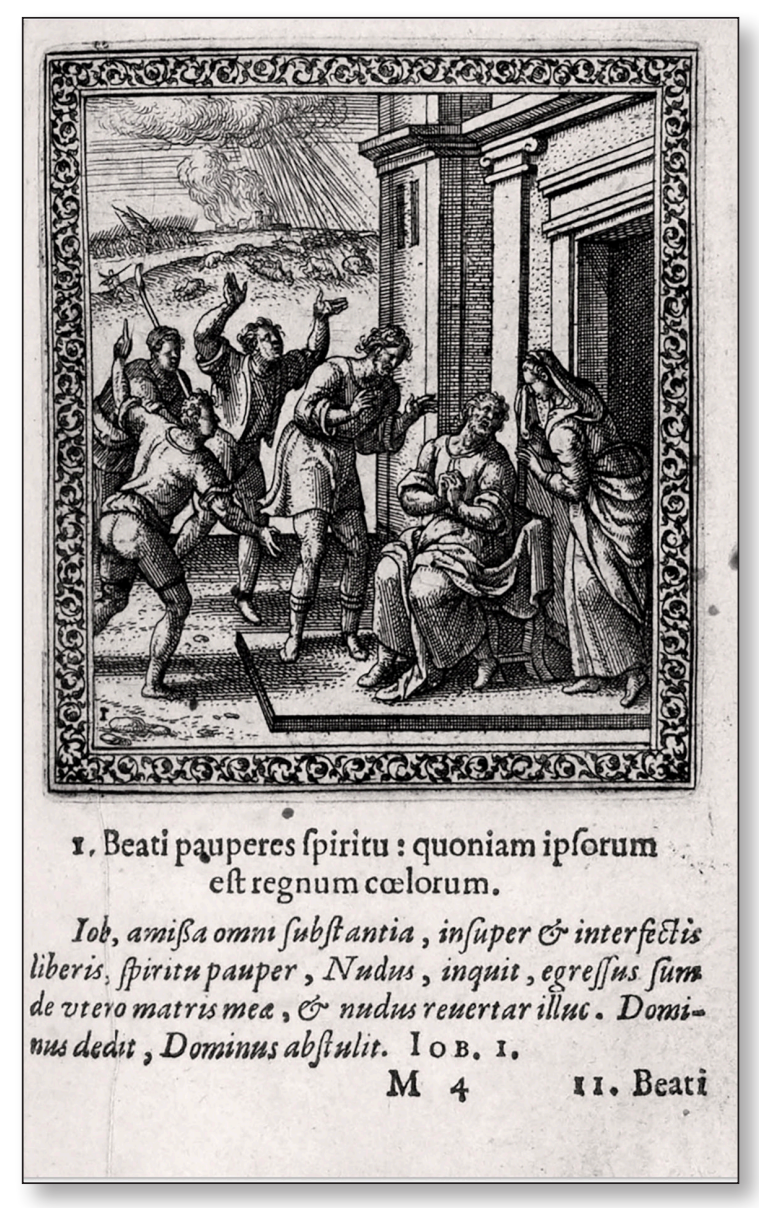

Fig. 8. Canisio, 1589: 183. 
Benditos los pobres de espíritu:

porque de ellos es Reino de los Cielos. (Ma. 5)

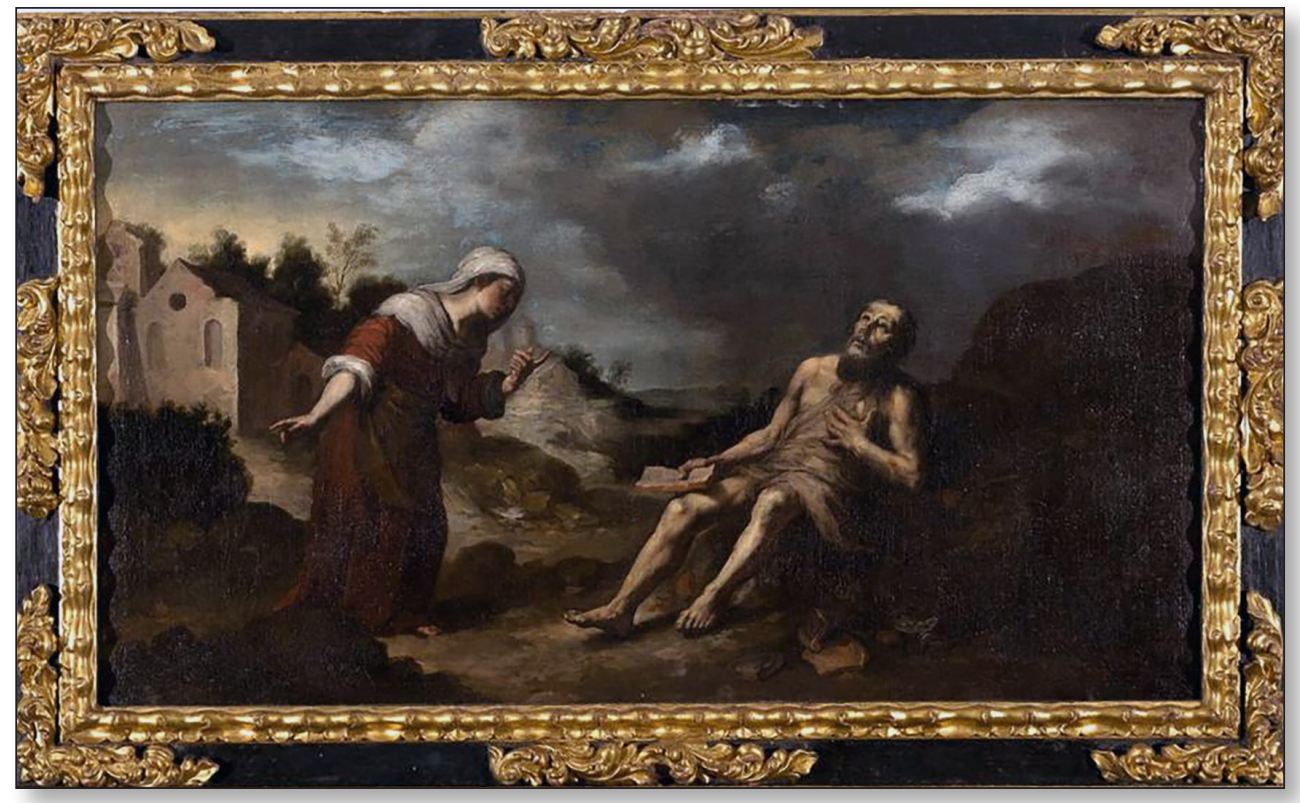

Fig. 9 Murillo, La paciencia del Santo Job, Sevilla, c. 1655, Colección del Marqués de Salamanca.

Job, perdidas todas las riquezas

Job $I$

e incluso muertos todos sus hijos,

pobre de espíritu, exclamó:

«Desnudo salí del vientre de mi madre

y desnudo a él volveré.

El Señor me lo dio,

el Señor me lo quitó»

En conclusión: tanto las composiciones que conforman los catecismos y sumas doctrinales emblematizadas, como muchos de los cuadros y otras composiciones artísticas que de ellos se derivan, pueden ser considerados emblemas en puridad y no en sentido traslaticio. Son un tipo de emblemas al que se puede denominar emblemas doctrinales. 


\section{BIBLIOGRAFÍA}

Alciato A. (2003). Los emblemas de Alciato traducidos en rimas españolas, Edición de Rafael Zafra, Palma de Mallorca, Olañeta

Alciato, A. (1591). Emblemata, Leyden, Officina Plantiniana / Franciscus Raphelengius, 1591.

Arellano, I y Martínez Pereira, A. (2010), Emblemática y religión en la Península Ibérica, Madrid, Iberoamericana Vervuert.

Butron, J. (1626). Discursos apologéticos, en que se defiende la ingenuidad del arte de la pintura..., Madrid, Luis Sanchez.

Canisio, P. [2014]. Doctrina cristiana, ed. Edición, estudio y notas de Rafael Zafra, Palma de Mallorca, Olañeta.

Canisio, P. [1589]. Institutiones christianæe, seu Parvus catechismus catholicorum, præcipua christiana pietatis capita complectens,... iuxta SS. Concilii Tridentini decretum sess. 25, imaginibus distinctus, nunc vero aereis formis ad D. Petri Canisii, expressus... Antuerpia, Christophorus Plantinus \& Philippo Gallæo, 1589.

Cano, M. [2006], De locis theologicis, ed. J. Belda Plans, Madrid, BAC:

López PozA, S. [1993]. "Los emblemas y jeroglíficos médicos de Louis de Caseneuve», Cuadernos de arte e iconografía, 6,12, 9-21.

Melanchthon, F. (1583) Epigrammata Philippi Melanthonis selectiora..., Francfort, Sigismundo Feyrabend.

Melanchthon, F. (1521). Loci communes rerum theologicarum, Wittenberg, Melchior Lotter

Tung, M. [2010\}). The Variorum Edition of Alciato's Emblemata, https://www.emblems.arts.gla. ac.uk/alciato/tung/alciatotungedition-000.pdf.

ZAFrA, R. [2017]. "La transfiguración del lugar común: de lo tópico a lo emblemático», en A. Bernat, B. Ballester, y J. T. Cull (eds), Encrucijada de la palabra y la imagen simbólicas, Palma de Mallorca, Olañeta

ZAFrA, R. [2014]. "Los icones de varones ilustres: un género emblemático», Imago: revista de emblemática y cultura visual, 6, 129-143. <http://dx.doi.org/10.7203/imago.6.4280>

Zafra, R. [2010]. "El prudente Tiziano y su emblema de la prudencia», Potestas: Religión, poder y monarquía. Revista del Grupo Europeo de Investigación Histórica, 3, 123-146.

ZaFrA, R. [2009]. Emblema? Imago auctoritatis, en I. Arellano, C. Strosetzki y E. Williamson (eds) Autoridad y poder en el Siglo de Oro, Madrid, Iberoamericana Vervuert.

ZAFra, R. [2008]. "El emblemático catecismo de la Compañía de Jesús y su influencia en la formación del imaginario doctrina de la Contrarreforma», en R. García Mahiques y V. Zuriaga Senent (eds.), Imagen y cultura: la interpretación de las imágenes como historia cultural, Valencia, Biblioteca Valenciana, 2, 1523-1536. 
